\title{
KEKUATAN ALAT BUKTI INFORMASI ELEKTRONIK DALAM PENYIDIKAN TINDAK PIDANA KEIMIGRASIAN
}

\author{
(The Power of Electronic Information as Evidence in \\ The Investigation of Immigration-Related Crimes)
}

\author{
Budy Mulyawan \\ Politeknik Imigrasi \\ Badan Pengembangan Sumber Daya Manusia Hukum dan HAM \\ Kementerian Hukum dan HAM R.I. \\ Jalan Raya Gandul, Cinere, Depok, Jawa Barat \\ Email: budymulyawan23@gmail.com
}

Tulisan Diterima: 15 Januari 2018; Direvisi: 4 Maret 2018; Disetujui Diterbitkan: 19 Maret 2018

DOI: http://dx.doi.org/10.30641/kebijakan.2018.V12.107-118

\begin{abstract}
Abstrak
Fungsi penegakan hukum Keimigrasian dilaksanakan yaitu dalam bentuk Tindakan Administratif Keimigrasian dan Tindakan yang bersifat Pro Justitia atau penyidikan.Dalam melakukan penyidikan, Penyidik Pegawai Negeri Sipil (PPNS) Keimigrasian terkadang menghadapi suatu permasalahan yaitu penggunaan alat bukti yang ada sekarang dirasa sangat terbatas mengingat perubahan yang cukup pesat dalam masyarakat. Dalam alat bukti pemeriksaan tindak pidana Keimigrasian terdapat 2 (dua) alat bukti di luar Kitab Undang-undang Hukum Acara Pidana (KUHAP), salah satunya adalah alat bukti informasi elektronik, yang dapat dijadikan sebagai alat bukti tambahan dalam proses pemeriksaan. Penerapan terhadap alat bukti informasi elektronik tersebut masih jarang digunakan sehingga tingkat efektivitasnya dinilai kurang. Meskipun pada umumnya alat bukti tersebut baru diperlukan apabila alat bukti yang lain belum mencukupi batas minimum pembuktian yang digariskan dalam peraturan perundang-undangan.
\end{abstract}

Kata Kunci: Alat Bukti, Informasi Elektronik, Penyidikan

\begin{abstract}
The law enforcement function of immigration affairs is implemented in the forms of Immigration Administrative Actions and other Actions that are Pro Justitia or investigation in nature. When conducting investigations, Immigration Civil Servant Investigator (PPNS) sometimes encounter an issue in using evidences which are currently extremely limited amid the rapid changes that happened to the people. In the investigation of immigration-related crime, there are two (2) evidences not provided for in the Indonesian Penal Procedural Code (KUHAP), one of them is the electronic information evidence, that may be submitted as additional evidences during the examination processes. The evidence in the form of electronic information has seldom been used, as its effectiveness is considered less reliable. Nevertheless, in general, the evidence may be required if the other evidences have failed to meet the minimum requirements of evidencing processes provided for in the applicable laws and regulations.
\end{abstract}

Keywords: Evidence, Electronic Information, Investigation

\section{PENDAHULUAN}

\section{Latar Belakang}

Dunia yang semakin berkembang berakibat pada biasnya batas-batas negara yang dapat memisahkan antara negara satu dengan negara lain. Semakin kompleksnya persoalan yang dihadapi oleh masyarakat suatu negara akan mengakibatkan pesatnya perpindahan penduduk lintas negara yang akan diimbangi dengan berkembangya bentuk kejahatan sehingga bukan tidak mungkin 
menimbulkan masalah yang dapat mengganggu kedaulatan Negara. Dalam halnya penerapan kebijakan bebas visa kunjungan bagi 169 (seratus enam puluh sembilan) negara yang masuk wilayah Indonesia menimbulkan dampak signifikan bagi Indonesia. Dampak positifnya dapat dilihat dari berbagai sektor seperti sektor pariwisata maupun pendapatan negara. Namun dalam hal ini kita juga tidak dapat mengesampingkan dampak negatif yang telah muncul juga pada berbagai sektor, seperti sektor ketenagakerjaan maupun di sektor teknologi informasi. Perkembangan tindak pidana lintas batas antarnegara ini melibatkan warga Negara asing yang dalam keberadaan dan kegiatannya diawasi oleh Keimigrasian.

Keimigrasian adalah hal inwal lalu lintas orang yang masuk atau keluar wilayah Indonesia serta pengawasannya dalam rangka menjaga tegaknya kedaulatan negara ${ }^{1}$. Dengan demikian, Imigrasi di samping termasuk salah satu instansi pemerintah yang salah satu kegiatannya melayani administrasi Keimigrasian masyarakat, juga sebagai instansi pengawas terhadap segala keberadaan dan kegiatan orang asing. Terhadap Orang Asing pelayanan dan pengawasan di bidang Keimigrasian dilaksanakan berdasarkan prinsip selektif (selective policy). Berdasarkan prinsip ini maka Orang Asing yang dapat diberikan ijin masuk ke Indonesia hanyalah Orang Asing yang memiliki manfaat bagi kesejahteraan rakyat, bangsa, dan Negara Kesatuan Republik Indonesia (NKRI), tidak membahayakan keamanan dan ketertiban, serta tidak bermusuhan dengan rakyat dan pemerintah.

Pengawasan terhadap Orang Asing tidak hanya dilakukan pada saat mereka masuk, tetapi juga selama mereka berada di Wilayah Indonesia, termasuk kegiatannya. Pengawasan Keimigrasian mencakup penegakan hukum Keimigrasian, baik yang bersifat administratif maupun tindak pidana Keimigrasian. Penegakan hukum Keimigrasian memerlukan tindak lanjut melalui suatu penindakan jika terdapat suatu penyimpangan. Penindakan yang dimaksud di bidang Keimigrasian adalah penindakan justitia melalui proses peradilan dan penindakan non justitia tanpa melalui proses peradilan berupa Tindakan Administratif Keimigrasian.

\footnotetext{
1 Indonesia, Undang-undang Nomor 6 Tahun 2011 tentang Keimigrasian, Pasal. 1 angka 1. 108
}

Penindakan yang diselesaikan melalui proses peradilan dilakukan melalui proses penyidikan berdasarkan ketentuan Undang-undang Nomor 6 Tahun 2011 tentang Keimigrasian yang dilaksanakan sesuai asas dan kaedah prosedur hukum sesuai Hukum Acara Pidana dalam Undang-undang Nomor 8 Tahun 1981 tentang Kitab Undang-undang Hukum Acara Pidana (KUHAP), sedang tanpa melalui proses peradilan berupa Tindakan Administratif Keimigrasian yang bersifat tindakan administratif dalam bidang Keimigrasian di luar proses peradilan. Tindak Pidana Keimigrasian merupakan tindak pidana khusus sehingga hukum formal dan hukum materiilnya berbeda dengan hukum pidana umum.

Penyidikan merupakan serangkaian tindakan penyidik dalam hal dan menurut cara yang diatur dalam Undang-Undang ini untuk mencari serta mengumpulkan bukti yang dengan bukti itu membuat terang tentang tindak pidana yang terjadi dan guna menemukan tersangkanya. ${ }^{2}$ Pemeriksaan perkara tindak pidana Keimigrasian memerlukan dukungan alat bukti yang sah agar dapat dipastikan telah terjadi tindak pidana sebagaimana diatur dalam Undang-undang Nomor 6 Tahun 2011 tentang Keimigrasian. Penyidik harus lebih dulu memperoleh atau mengumpulkan bukti permulaan, baru dapat menjatuhkan dugaan terhadap seseorang. Artinya cukup fakta dan keadaan berdasar informasi yang sangat dipercaya bahwa tersangka sebagai pelaku tindak pidana berdasar bukti dan tidak boleh semata-mata berdasar konklusi. ${ }^{3}$ Keberhasilan suatu proses peradilan pidana sangat bergantung pada alat bukti khususnya dalam perkara tindak pidana Keimigrasian. Berdasarkan Undang-Undang Nomor 8 Tahun 1981 tentang Hukum Acara Pidana Pasal 183, hakim tidak boleh menjatuhkan pidana kepada seorang kecuali dengan sekurang-kurangnya dua alat bukti yang sah ia memperoleh keyakinan bahwa suatu tindak pidana benarbenar terjadi dan bahwa terdakwalah yang bersalah melakukannya. Pasal 183 jo 184 KUHAP ini juga menjadi dasar bagi seorang

\footnotetext{
${ }^{2}$ Undang-undang Nomor 8 Tahun 1981 tentang Hukum Acara Pidana, Ps. 1 angka 2.

${ }^{3}$ M. Yahya Harahap, Pembahasan Permasalahan dan Penerapan KUHAP - Penyidikan dan Penuntutan, (Jakarta: Sinar Grafika, 2008), hlm. 125-126.
} 
penyidik untuk menentukan awal untuk memulai suatu penyidikan tindak pidana Keimigrasian $($ SPDP $=$ Surat Perintah Dimulainya Penyidikan), yang harus dilakukan secara cermat, teliti, cerdas, bertanggung jawab, atas Undang-undang Nomor 6 tahun 2011 tentang Keimigrasian.

Undang-undang Keimigrasian selain mengatur bidang Keimigrasian umum juga mencantumkan ketentuan pidana dan alat bukti yang berhubungan dengan tindak pidana Keimigrasian. Ketentuan pidana ini merupakan pedoman bagi aparat penegak hukum baik aparat imigrasi maupun bagi peradilan dalam memeriksa dan memutus perkara tindak pidana yang menyangkut bidang Keimigrasian. Alat bukti mempunyai fungsi yang sangat penting dalam pemeriksaan suatu perkara pidana. Permasalahan alat bukti kerap membawa kesulitan baik dari instansi Imigrasi selaku PPNS Keimigrasian, lembaga Kejaksaan selaku penuntut maupun lembaga Pengadilan dalam memeriksa dan memutus perkara. Ketentuan tentang alat bukti pemeriksaan tindak pidana Keimigrasian menurut Pasal 108 UndangUndang Nomor 6 Tahun 2011 tentang Keimigrasian berupa :

1. Alat bukti sebagaimana dimaksud dalam hukum acara pidana;

2. Alat bukti lain berupa informasi yang diucapkan, dikirimkan, diterima atau disimpan secara elektronik atau yang serupa dengan itu; dan

3. Keterangan tertulis dari Pejabat Imigrasi yang berwenang.

Alat bukti yang ada sekarang dirasa sangat terbatas mengingat perubahan yang cukup pesat dalam masyarakat. Dalam alat bukti pemeriksaan tindak pidana Keimigrasian tersebut dicantumkan 2 (dua) alat bukti di luar KUHAP yang dapat dijadikan sebagai alat bukti tambahan dalam proses pemeriksaan. Penerapan terhadap 2 (dua) alat bukti tersebut masih jarang digunakan sehingga tingkat efektivitasnya dinilai kurang. Meskipun pada umumnya alat bukti tersebut baru diperlukan apabila alat bukti yang lain belum mencukupi batas minimum pembuktian yang digariskan dalam Pasal 183 KUHAP. Untuk menghindari atau setidaknya meminimalkan putusan pengadilan yang memberikan putusan bebas maupun keringanan sanksi pada pihak yang sebenarnya bersalah, kecermatan dalam menilai alat bukti pada saat pemeriksaan sangat diharapkan, khususnya dalam kasus tindak pidana Keimigrasian.

Berkembangnya teknologi pada saat ini memungkinkan masyarakat semakin mudah untuk berkomunikasi tanpa dibatasi jarak dan waktu, serta memudahkan pengguna untuk saling bertukar informasi. Namun tidak dapat dipungkiri juga bahwa kemajuan teknologi pada saat ini juga sangat potensial terhadap munculnya berbagai bentuk tindak pidana, internet dapat menjadi media yang memudahkan seseorang melakukan tindak pidana berbasis teknologi informasi atau yang dikenal dengan istilah cybercrime. Informasi elektronik yang diperoleh dalam suatu tindak pidana tersebut yang dapat dijadikan alat bukti dalam pemeriksaan tindak pidana.

Dalam hal ini telah disebutkan mengenai alat bukti pemeriksaan tindak pidana Keimigrasian dalam Pasal 108 huruf (b) Undang-undang Nomor 6 Tahun 2011 tentang Keimigrasian mengenai alat bukti lain berupa informasi yang diucapkan, dikirimkan, diterima atau disimpan secara elektronik atau yang serupa dengan itu dapat dihubungkan dengan jenis alat bukti yang diatur Undang-Undang Nomor 11 Tahun 2008 tentang Informasi dan Transaksi Elektronik. Berdasarkan isi Pasal 108 huruf (b) di atas maka adanya alat bukti yang disebut dengan informasi elektronik dan/atau dokumen elektronik bisa dengan mudah digunakan untuk membuktikan tindak pidana Keimigrasian yang diatur dalam UU Keimigrasian karena alat bukti tersebut merupakan perluasan dari alat bukti yang diatur dalam Pasal 108 huruf (a).

PPNS Keimigrasian sampai dengan saat ini belum pernah menggunakan alat bukti informasi elektronik untuk menjerat pelaku tindak pidana Keimigrasian. Hal ini disebabkan karena belum adanya alat digital forensik yang memadai untuk mengolah alat bukti tindak pidana Keimigrasian khususnya alat bukti yang diucapkan, dikirimkan, diterima, atau disimpan secara elektronik. Selain itu. Selain itu belum adanya PPNS Keimigrasian yang memiliki pengetahuan dalam memeriksa dan mengolah alat bukti informasi elektronik menjadi kendala sehingga alat bukti informasi elektronik belum pernah digunakan dalam menyidik suatu tindak pidana Keimigrasian. 


\section{Rumusan Masalah}

Berdasarkan latar belakang yang telah diuraikan diatas, maka masalah yang dapat dirumuskan adalah sebagai berikut :

1. Bagaimana kedudukan alat bukti Pasal 108 huruf (b) Undang-undang Nomor 6 Tahun 2011 tentang Keimigrasian dalam penyidikan tindak pidana Keimigrasian?

2. Bagaimana kekuatan pembuktian alat bukti Pasal 108 huruf (b) Undang-undang Nomor 6 Tahun 2011 tentang Keimigrasian dalam pembuktian tindak pidana Keimigrasian?

\section{Tujuan Penulisan}

Adapun tujuan penulisan yaitu :

1. Untuk mengetahui kedudukan alat bukti Pasal 108 huruf (b) Undang-undang Nomor 6 Tahun 2011 tentang Keimigrasian dalam pemeriksaan tindak pidana Keimigrasian.

2. Untuk mengetahui kekuatan pembuktian alat bukti Pasal 108 huruf (b) Undang-undang Nomor 6 Tahun 2011 tentang Keimigrasian dalam pembuktian tindak pidana Keimigrasian.

\section{Metode Penelitian}

1. Jenis Penelitian

Jenis penelitian ini adalah penelitian yuridis normatif, yakni penelitian dengan studi pustaka terhadap bahan-bahan hukum. Penelusuran bahan-bahan hukum tersebut dapat dilakukan dengan membaca, melihat, mendengarkan, maupun sekarang banyak dilakukan penelusuran bahan hukum tersebut melalui media internet.

2. Teknik Pengumpulan Data

a. Sumber Data

yaitu data yang diperoleh dari sumbersumber kepustakaan. Dalam penelitian hukum data sekunder itu dapat diklasifikasikan menjadi 3 (tiga), yaitu: bahan hukum primer adalah peraturan perundangundangan dan dokumen resmi yang berhubungan erat dengan permasalahan yang diteliti. Bahan hukum penelitian ini bersumber dari KUHP, KUHAP, Undangundang Nomor 11 Tahun 2008 tentang Informasi dan Transaksi Elektronik, Undangundang Nomor 6 Tahun 2011 tentang
Keimigrasian; bahan hukum sekunder adalah bahan-bahan hukum yang memberikan penjelasan mengenai bahan hukum primer; bahan hukum tersier adalah bahan hukum yang memberikan petunjuk maupun penjelasan terhadap bahan hukum primer dan sekunder, sebagai contoh adalah kamus, ensiklopedi hukum, dan sarana-sarana pendukung lainnya.

b. Teknik Pengumpulan Data

Melalui Kepustakaan yaitu upaya penulis untuk mengumpulkan data dengan mempelajari sumber-sumber tertulis diantaranya buku-buku dan tulisan yang berhubungan dengan pembuktian.

\section{Teknik Analisis Data}

Dalam penelitian ini menggunakan analisa kualitatif dengan menyederhanakan data ke dalam bentuk yang lebih mudah dibaca dan diinterpretasikan. Analisa ini memandang data sebagai produk dari proses memberikan interprestasi pada peneliti yang didalamnya sudah terkandung makna yang mempunyai referensi pada nilai. Kegiatan analisis dalam penelelitian kualitatif hanya merupakan rekonstruksi sebelumnya. Dari pandangan tersebut penelitian kualitatif memproses data penelitian dari reduksi data, penyajian data sampai pada pengambilan kesimpulan.

\section{PEMBAHASAN}

\section{Kedudukan Alat Bukti Informasi Elektronik Dalam Penyidikan Tindak Pidana Ke- imigrasian}

Dalam pemeriksaan tindak pidana Keimigrasian diperlukan alat bukti guna proses pemberkasan serta mendukung penilaian hakim dalam menjatuhkan hukuman bagi terdakwa yang melakukan pelanggaran tindak pidana Keimigrasian. Dalam Undang-undang nomor 6 tahun 2011 tentang Keimigrasian telah disebutkan bahwa terdapat alat bukti di luar KUHAP terkait dengan suatu alat bukti informasi elektronik yang tercantum dalam undangundang Keimigrasian yaitu alat bukti lain berupa informasi yang diucapkan, dikirimkan, diterima, atau disimpan secara elektronik atau yang serupa dengan itu. Secara eksplisit, KUHAP memang tidak mengatur alat bukti informasi elektronik. Dasar hukum penggunaan alat bukti informasi elektronik di pengadilan menjadi 
semakin jelas setelah diundangkannya UU Nomor 11 Tahun 2008 tentang Informasi dan Transaksi Elektronik (UU ITE).

Terdapat korelasi antara alat bukti yang terdapat dalam Pasal 108 huruf (b) UU Keimigrasian dengan alat bukti Pasal 5 UU ITE. Lebih lanjut mengenai korelasi alat bukti informasi elektronik dalam UU Keimigrasian ini diatur dalam Pasal 5 UU ITE, yaitu :

(1)Informasi Elektronik dan/atau Dokumen Elektronik dan/atau hasil cetaknya merupakan alat bukti hukum yang sah.

(2) Informasi Elektronik dan/atau Dokumen Elektronik dan/atau hasil cetaknya sebagaimana dimaksud pada Ayat (1) merupakan perluasan dari alat bukti yang sah sesuai dengan Hukum Acara yang berlaku di Indonesia.

(3)Informasi Elektronik dan/atau Dokumen Elektronik dinyatakan sah apabila menggunakan Sistem Elektronik sesuai dengan ketentuan yang diatur dalam Undang-Undang ini.

(4)Ketentuan mengenai Informasi Elektronik dan/atau Dokumen Elektronik sebagaimana dimaksud pada Ayat (1) tidak berlaku untuk:

i. surat yang menurut Undang-Undang harus dibuat dalam bentuk tertulis; dan

ii. surat beserta dokumennya yang menurut Undang-Undang harus dibuat dalam bentuk akta notaris atau akta yang dibuat oleh pejabat pembuat akta. ${ }^{4}$

Penjelasan lebih lanjut mengenai Pasal 5 ini dicantumkan dalam Penjelasan atas Undang-undang Republik Indonesia Nomor 19 Tahun 2016 tentang Perubahan atas Undang-undang Nomor 11 Tahun 2008 tentang Informasi dan Transaksi Elektronik sebagai berikut :

(1) Bahwa keberadaan Informasi Elektronik dan/atau Dokumen Elektronik mengikat dan diakui sebagai alat bukti yang sah untuk memberikan kepastian hukum terhadap Penyelenggaraan Sistem Elektronik dan Transaksi Elektronik, terutama dalam pembuktian dan hal yang berkaitan dengan perbuatan hukum yang dilakukan melalui Sistem Elektronik.

\footnotetext{
${ }^{4}$ Indonesia, Undang-undang Nomor 11 Tahun 2008 tentang Informasi dan Transaksi Elektronik, Pasal. 5.
}

(2) Khusus untuk Informasi Elektronik dan/atau Dokumen Elektronik berupa hasil intersepsi atau penyadapan atau perekaman yang merupakan bagian dari penyadapan harus dilakukan dalam rangka penegakan hukum atas permintaan kepolisian, kejaksaan, dan/atau institusi lainnya yang kewenangannya ditetapkan berdasarkan undang-undang.

(3) Cukup jelas.

(4) Huruf a

Surat yang menurut undang-undang harus dibuat tertulis meliputi tetapi tidak terbatas pada surat berharga, surat yang berharga, dan surat yang digunakan dalam proses penegakan hukum acara perdata, pidana, dan administrasi negara.

(5) Huruf b Cukup jelas. $^{5}$

Dalammenjabarkan kedudukan alat bukti informasi elektronik yang serupa dengan bunyi pasal dalam Undang-undang Nomor 6 Tahun 2011 tentang Keimigrasian, berdasarkan Pasal 5 Undang-undang ITE terdapat beberapa peraturan perundang-undangan hukum pidana yang menerangkan tentang alat bukti informasi elektronik, antara lain :

1. Undang-undang Nomor 8 Tahun 1997 tentang Dokumen Perusahaan

2. Undang-undang Nomor 20 Tahun 2001 tentang Perubahan Atas Undang-undang Nomor 31 Tahun 1999 tentang Pemberantasan Tindak Pidana Korupsi

3. Undang-undang Nomor 15 Tahun 2003 tentang Penetapan Peraturan Pemerintah Pengganti Undang-undang Nomor 1 Tahun 2002 tentang Pemberantasan Tindak Pidana Terorisme, menjadi Undang-undang

4. Undang-undang Nomor 21 Tahun 2007 tentang Pemberantasan Tindak Pidana Perdagangan Orang

5. Undang-undang Nomor 35 Tahun 2009 tentang Narkotika

6. Undang-undang Nomor 8 Tahun 2010 tentang Pencegahan dan Pemberantasan Tindak Pidana Pencucian Uang

\footnotetext{
${ }^{5}$ Indonesia, Penjelasan atas Undang-undang Republik Indonesia Nomor 19 Tahun 2016 tentang Perubahan atas Undang-undang Nomor 11 Tahun 2008 tentang Informasi dan Transaksi Elektronik, Angka 2.
} 
7. Undang-undang Nomor 9 Tahun 2013 tentang Pencegahan dan Pemberantasan Tindak Pidana Pendanaan Terorisme

8. Undang-undang Nomor 18 Tahun 2013 tentang Pencegahan dan Pemberantasan Perusakan Hutan

9. Undang-undang Nomor 28 Tahun 2014 tentang Hak Cipta

Pasal 108 huruf (b) UU Keimigrasian menyebutkan bahwa alat bukti lain berupa informasi yang diucapkan, dikirimkan, diterima, atau disimpan secara elektronik atau yang serupa dengan itu. Penjelasan lebih lanjut mengenai informasi elektronik tersebut terdapat dalam Pasal 1 angka 1 UU ITE yang menyebutkan bahwa Informasi Elektronik adalah satu atau sekumpulan data elektronik, termasuk tetapi tidak terbatas pada tulisan, suara, gambar, peta, rancangan, foto, electronic data interchange (EDI), surat elektronik (electronic mail), telegram, teleks, telecopy atau sejenisnya, huruf, tanda, angka, kode akses, simbol, atau perforasi yang telah diolah yang memiliki arti atau dapat dipahami oleh orang yang mampu memahaminya.

Apabila kita hubungkan pasal 108 huruf (b) tersebut dengan Pasal 5 UU ITE, di dalamnya tidak hanya terdapat informasi elektronik saja, melainkan juga dokumen elektronik. Yang dimaksud dengan Dokumen Elektronik adalah setiap Informasi Elektronik yang dibuat, diteruskan, dikirimkan, diterima, atau disimpan dalam bentuk analog, digital, elektromagnetik, optikal, atau sejenisnya, yang dapat dilihat, ditampilkan, dan/atau didengar melalui Komputer atau Sistem Elektronik, termasuk tetapi tidak terbatas pada tulisan, suara, gambar, peta, rancangan, foto atau sejenisnya, huruf, tanda, angka, kode akses, simbol atau perforasi yang memiliki makna atau arti atau dapat dipahami oleh orang yang mampu memahaminya sebagaimana yang diatur dalam Pasal 1 angka 4 UU ITE.

Pada prinsipnya Informasi Elektronik dapat dibedakan tetapi tidak dapat dipisahkan dengan Dokumen Elektronik. Informasi Elektronik ialah data atau kumpulan data dalam berbagai bentuk, sedangkan Dokumen Elektronik ialah wadah atau bungkus dari Informasi Elektronik. Sebagai contoh apabila kita berbicara mengenai file poster iklan dalam bentuk jpg maka semua informasi atau gambar yang keluar dari file tersebut ialah Informasi 112
Elektronik, sedangkan Dokumen Elektronik dari file tersebut ialah jpg.

Kedudukan alat bukti Pasal 108 huruf (b) dalam pemeriksaan tindak pidana Keimigrasian tersebut dianggap sama dengan alat bukti KUHAP yang lain. Karena di dalam KUHAP sendiri tidak ada tingkatan/hierarki manakah alat bukti yang seharusnya diajukan terlebih dahulu. Kedudukan alat bukti informasi elektronik dan dokumen elektronik serta hasil cetaknya merupakan perluasan alat bukti berdasarkan Pasal 184 KUHAP. Arti perluasan di sini harus dihubungkan dengan jenis alat bukti yang diatur dalam Pasal 5 ayat (1) UU ITE. Perluasan di sini maksudnya sebagai berikut:

1. Menambah alat bukti yang telah diatur dalam hukum acara pidana di Indonesia, misalnya KUHAP. Informasi Elektronik dan/atau Dokumen Elektronik sebagai Alat bukti informasi elektronik menambah jenis alat bukti yang diatur dalam KUHAP;

2. Memperluas cakupan dari alat bukti yang telah diatur dalam hukum acara pidana di Indonesia, misalnya dalam KUHAP. Hasil cetak dari Informasi atau Dokumen Elektronik merupakan alat bukti surat dan petunjuk yang diatur dalam KUHAP.

Dari perluasan alat bukti yang dimaksud di atas terlihat jelas terdapat dua pandangan yang berbeda, yaitu pada pandangan yang pertama bahwa bukti elektronik merupakan alat bukti yang berdiri sendiri. Alat bukti informasi elektronik tersebut terpisah dari alat bukti sebagaimana yang telah diatur dalam KUHAP. Pengaturannya dapat ditemukan dalam Undang-undang Nomor 15 Tahun 2003 tentang Penetapan Peraturan Pemerintah Pengganti Undang-undang Nomor 1 Tahun 2002 tentang Pemberantasan Tindak Pidana Terorisme, menjadi Undang-undang dan Undang-undang Nomor 21 Tahun 2007 tentang Pemberantasan Tindak Pidana Perdagangan Orang. Sedangkan pada pandangan yang kedua dapat diketahui bahwa alat bukti informasi elektronik tersebut masuk ke dalam pengkategorian bukti yang sudah ada, artinya tidak berdiri sendiri. Seperti contohnya dalam Undang-undang Nomor 8 Tahun 1997 tentang Dokumen Perusahaan mengingat dokumen elektronik merupakan bagian dari dokumen perusahaan dan dokumen perusahaan dimaksud merupakan bagian dari alat bukti surat. Kemudian dalam Undangundang Nomor 20 tahun 2001 tentang 
Perubahan Atas Undang-undang Nomor 31 Tahun 1999 tentang Pemberantasan Tindak Pidana Korupsi yang menyatakan bahwa alat bukti informasi elektronik merupakan perluasan dari alat bukti yang sah berupa petunjuk sebagaimana telah diterangkan dalam Penjelasan Umum Undang-undang Nomor 20 Tahun 2001.

Peraturan mengenai alat bukti dalam Undang-undang Nomor 6 Tahun 2011 tentang Keimigrasian dapat diketahui bahwa yang tercantum pada Pasal 108 huruf (b) dapat dikategorikan sebagai perluasan alat bukti yang pertama, yaitu menambah jenis alat bukti yang diatur dalam KUHAP. Karena dalam Pasal 108 huruf (b) tidak disebutkan bahwa alat bukti tersebut merupakan bagian dari alat bukti surat maupun petunjuk sesuai yang tercantum dalam KUHAP. Berdasarkan Pasal 108 huruf (b) yang mengacu pada Pasal 5 UU ITE tidak perlu lagi dipertentangkan apakah alat bukti informasi elektronik dan dokumen elektronik serta hasil cetaknya merupakan perluasan alat bukti surat ataupun alat bukti petunjuk, karena pada dasarnya alat bukti informasi elektronik dan hasil cetaknya pada pasal tersebut merupakan penambahan alat bukti baru selain yang ada dalam KUHAP. Karena alat bukti informasi elektronik dan dokumen elektronik itu memiliki sifat yang berbeda dengan alat bukti yang telah ada dalam Pasal 184 KUHAP. Serta di dalam KUHAP sendiri, telah dijelaskan masing-masing mengenai pengertian surat maupun petunjuk.

Penjelasan mengenai alat bukti surat dalam Pasal 187 KUHAP yaitu :

"Surat sebagaimana tersebut pada Pasal 184 ayat (1) huruf $c$, dibuat atas sumpah jabatan atau dikuatkan dengan sumpah, adalah :

a. berita acara dan surat lain dalam bentuk resmi yang dibuat oleh pejabat umum yang berwenang atau yang dibuat di hadapannya, yang memuat keterangan tentang kejadian atau keadaan yang didengar, dilihat atau yang dialaminya sendiri, disertai dengan alasan yang jelas dan tegas tentang keterangannya itu;

b. surat yang dibuat menurut ketentuan peraturan perundang-undangan atau surat yang dibuat oleh pejabat mengenai hal yang termasuk dalam tata laksana yang menjadi tanggung jawabnya dan yang diperuntukkan bagi pembuktian sesuatu hal atau sesuatu keadaan; c. surat keterangan dari seorang ahli yang memuat pendapat berdasarkan keahliannya mengenai sesuatu hal atau sesuatu keadaan yang diminta secara resmi dari padanya;

d. surat lain yang hanya dapat berlaku jika ada hubungannya dengan isi dari alat pembuktian yang lain. ${ }^{6}$

Surat sebagaimana yang dimaksud dalam KUHAP di atas hanya surat secara konvensional, sedangkan dokumen elektronik tidak hanya terbatas pada bentuk tulisan saja, melainkan juga gambar, peta, rancangan, foto, atau sejenisnya, huruf, tanda, angka, kode akses, simbol, atau perforasi yang memiliki makna atau arti atau dapat dipahami oleh orang yang mampu memahaminya. Sedangkan penjelasan mengenai alat bukti petunjuk sesuai pasal 188 KUHAP yaitu :

(1) Petunjuk adalah perbuatan, kejadian atau keadaan, yang karena persesuaiannya, baik antara yang satu dengan yang lain, maupun dengan tindak pidana itu sendiri, menandakan bahwa telah terjadi suatu tindak pidana dan siapa pelakunya.

(2) Petunjuk sebagaimana dimaksud dalam Ayat (1) hanya dapat diperoleh dari:

a. keterangan saksi;

b. surat;

c. keterangan terdakwa.

(3) Penilaian atas kekuatan pembuktian dari suatu petunjuk dalam setiap keadaan tertentu dilakukan oleh hakim dengan arif lagi bijaksana setelah ia mengadakan pemeriksaan dengan penuh kecermatan dan kesaksamaan berdasarkan hati nuraninya. ${ }^{7}$

Selanjutnya alasan mengapa alat bukti informasi elektronik tidak bisa dijadikan sebagai perluasan sumber perolehan alat bukti petunjuk karena mengingat untuk keberadaan alat bukti petunjuk itu digunakan setelah menghadirkan alat bukti lain. Padahal alat bukti informasi elektronik dan dokumen elektronik untuk beberapa kasus pidana bisa menjadi alat bukti utama dan pertama dalam pembuktian tindak pidana, seperti tindak pidana Keimigrasian.

\section{Kekuatan Pembuktian Alat Bukti Informasi Elektronik dalam Pembuktian Tindak Pidana Keimigrasian}

\footnotetext{
${ }^{6}$ Undang-undang Nomor 8 Tahun 1981 tentang Hukum Acara Pidana, Ps. 187.

${ }^{7}$ Ibid, Psl. 188.
} 
Pembuktian merupakan proses yang sangat penting dalam persidangan untuk mengetahui kebenaran hal-hal yang dikemukakan oleh para pihak dalam persidangan. Kebenaran dari suatu peristiwa ini hanya dapat diperoleh melalui pembuktian, melalui pembuktian ini jugalah ditentukan nasib terdakwa. Untuk dapat menjatuhkan putusan yang adil, hakim harus mengenal peristiwa yang harus dibuktikan kebenarannya. Selain itu, para hakim juga harus hati-hati, cermat dan matang menilai dan mempertimbangkan masalah pembuktian.

Dalam Hukum Acara Pidana, terdapat teori pembuktian. Dalam perkembangannya ilmu pengetahuan hukum mengenal ada empat (4) sistem pembuktian, yakni: ${ }^{8}$

1. Sistem Pembuktian Berdasarkan Undang-Undang Secara Positif (Positive Wettelijk Bewijstheorie). Pembuktian menurut Undang-undang secara positif merupakan pembuktian yang bertolak belakang dengan sistem pembuktian menurut keyakinan atau conviction in time. Disebut demikian karena hanya didasarkan kepada undang-undang melulu.

2. Pembuktian berdasarkan keyakinan hakim belaka (conviction in time). Sistem pembuktian conviction in time ini menentukan salah tidaknya seorang terdakwa, semata-mata ditentukan oleh penilaian keyakinan hakim.

3. Sistem pembuktian berdasarkan keyakinan hakim atas alasan logis (conviction raisonnee/convictim-raisonnee). Sistem atau teori pembuktian ini disebut juga pembuktian bebas karena hakim bebas menyebutkan alasan-alasan keyakinanya ( vrije bewijstheorie).

4. Sistem pembuktian Undang-undang Secara Negatif (Negatief Wettelijk stelsel). Pada prinsipnya, sistem pembuktian menurut Undang-undang negatif (negatief wettlijke bewijs theorie) menentukan bahwa hakim hanya boleh menjatuhkan pidana terhadap terdakwa apabila alat bukti tersebut secara limitatif ditentukan oleh Undang-undang dan didukung pula oleh adanya keyakinan hakim terhadap eksistensi alat-alat bukti tersebut.

\footnotetext{
${ }^{8}$ Andi Hamzah, Hukum Acara Pidana Indonesia, Sinar Grafika, Jakarta, 2004, hlm. 256-257.

114

Undang-Undang Nomor 11 Tahun 2008 tentang Informasi dan Transaksi Elektronik (UU ITE) memberikan dasar hukum mengenai kekuatan hukum alat bukti informasi elektronik dan syarat formil dan materil alat bukti informasi elektronik agar dapat diterima di persidangan. Pasal 5 Ayat (1) UU ITE mengatur bahwa Informasi Elektronik dan/atau Dokumen Elektronik dan/atau hasil cetaknya merupakan alat bukti hukum yang sah di pengadilan. Pasal 5 Ayat (2) UU ITE mengatur bahwa Informasi Elektronik dan/atau Dokumen Elektronik dan/atau hasil cetaknya merupakan perluasan dari alat bukti hukum yang sah sesuai dengan hukum acara yang berlaku di Indonesia. Yang dimaksud dengan perluasan di sini maksudnya adalah menambah alat bukti yang telah diatur dalam hukum acara pidana di Indonesia, dimana informasi elektronik dan/atau dokumen elektronik sebagai alat bukti informasi elektronik menambah jenis alat bukti yang diatur dalam KUHAP.

Dalam UU ITE alat bukti dapat dikelompokkan menjadi dua bagian. Pertama Informasi Elektronik dan/atau Dokumen Elektronik. Kedua, hasil cetak dari Informasi Elektronik dan/atau hasil cetak dari Dokumen Elektronik. Oleh sebab itu, maka agar informasinya dapat dipercaya, ada otoritas data tertentu yang bertanggung jawab mengelola dokumen elektronik di suatu lembaga. Untuk menutupi kelemahan otoritas data yang belum semua dimiliki di berbagai lembaga, maka hasil cetakan dokumen elektronik masih diperlukan dalam proses pembuktian karena ada otentikasi dari pihak terkait.

Saat ini hukum pidana Indonesia belum mengatur tentang kekuatan bukti elektronik pada proses pembuktian di persidangan. Ketika bukti elektronik dihadirkan di persidangan akan mengundang perdebatan mengenai bagaimana teknis penilaian terhadap bukti elektronik tersebut. Belum adanya Undang-undang yang mengatur teknis penilaian bukti elektronik, maka Hakim diharapkan mampu menentukan teknis penilaian terhadap kekuatan bukti elektronik. Dalam perkara Tindak Pidana Umum, ketentuan mengenai alat bukti informasi elektronik belum diatur secara khusus dalam KUHAP, sehingga Hakim harus melakukan penemuan hukum untuk mencegah terjadinya kekosongan 
hukum. ${ }^{9}$ Hakim sebagai aparat penegak hukum yang memeriksa, mengadili dan memutus perkara tidak boleh menolak perkara yang diajukan kepadanya dengan alasan Undangundangnya tidak lengkap atau tidak jelas, sehingga Hakim dapat menggunakan metode argumentasi karena KUHAP belum mengatur secara khusus mengenai ketentuan bukti elektronik. Dalam hukum pembuktian pidana di Indonesia, secara yuridis belum mengakomodasikan dokumen atau informasi dalam bentuk elektronik sebagai alat bukti dalam penyelesaian sengketa melalui Pengadilan. Di masa lalu alat bukti yang dapat diterima di pengadilan terbatas pada alat-alat bukti yang bersifat materiil, yaitu alat bukti yang dapat dilihat dan diraba dan sesuai Pasal 184 KUHAP, alat bukti yang diperkenankan dalam Hukum Acara Pidana yaitu Keterangan Saksi, Keterangan Ahli, Surat, Petunjuk, dan Keterangan Terdakwa. Secara tertulis seluruh alat bukti yang disebutkan dalam KUHAP tersebut tidak mengakomodir alat bukti informasi elektronik.

Untuk memudahkan dalam proses pembuktian di persidangan, alat bukti informasi elektronik tidak diperlukan bentuk aslinya (soft copy), yang diperlukan hanya hasil cetakannya (print out). Namun tidak menutup kemungkinan juga bentuk aslinya ditampilkan dalam persidangan. Hal ini mengacu kepada Pasal 5 Ayat (1) Undang-Undang No.11 Tahun 2008. Mengenai aspek keaslian dari hasil cetakan (printout) informasi elektronik, hakim akan menanyakan kepada terdakwa atau korban mengenai informasi elektronik tersebut apakah terdapat perbedaan dari bentuk aslinya, jika terdakwa atau korban mengakui bahwa surat elektronik tersebut sama dengan aslinya atau tidak terdapat perbedaan maka informasi elektronik tersebut telah memenuhi aspek keaslian sebagai alat bukti dan menjadi alat bukti yang sah. Apabila salah satu pihak tidak mengakuinya, maka diperlukan keterangan ahli untuk menentukan sah atau tidaknya hasil cetak dari surat elektronik tersebut, dan keterangan ahli tersebut akan menjadi dasar pertimbangan

\footnotetext{
9 "Pengkajian : Kekuatan Nilai Pembuktian Terhadap Alat bukti informasi elektronik Dalam Penanganan Tindak Pidana," Kejaksaan Republik Indonesia : https://www.kejaksaan.go.id/unit kejaksaan.php?idu=28 \&idsu=35\&id=4183. 20 Agustus 2017.
}

hakim dalam menentukan sah atau tidaknya hasil cetak (printout) surat elektronik sebagai alat bukti dalam persidangan. Keterangan ahli mengenai alat bukti informasi elektronik ini dapat dibagi menjadi 2 (dua), yaitu ahli digital forensik dan ahli hukum. Keduanya memiliki tugas yang berbeda, diamana ahli digital forensik lebih fokus pada memeriksa keabsahan dari alat bukti sedangkan ahli hukum lebih fokus pada tindak pidana maupun pasal apa yang dilanggar oleh pelaku yang terdapat dalam alat bukti tersebut.

Pada hakekatnya, dalam hukum acara pidana, kekuatan semua alat bukti dalam pembuktian itu sama, tidak ada satu melebihi yang lain seperti kedudukan alat bukti dalam pemeriksaan tindak pidana. Alat bukti dalam hukum acara pidana tidak mengenal hierarki. Hanya saja ada ketentuan-ketentuan yang mensyaratkan keterkaitan antara bukti yang satu dengan bukti yang lain. Oleh karena itu dalam hukum acara pidana terdapat bukti yang bersifat pelengkap.

Alat bukti informasi elektronik dan dokumen elektronik seperti yang terdapat dalam Pasal 108 huruf (b) UU Keimigrasian sangat rentan untuk dimanipulasi, sehingga keaslian alat bukti informasi elektronik dan dokumen elektronik serta autentifikasi digital forensik sangat penting dalam pembuktian. File asli dari sebuah hasil cetak haruslah dijamin keasliannya untuk menghindari adanya perubahan (editing) karena pada dasarnya sebuah data digital itu rentan oleh perubahan dari apapun maupun siapapun. Oleh karena itu dalam pembuktian ini perlu ketelitian dan kecermatan khusus baik dari pihak penyidik dan ahli dalam membuktikan suatu alat bukti informasi elektronik.

Dapat disimpulkan bahwa dalam hal kekuatan pembuktian, hakim memiliki peranan penting dalam menilai kekuatan dari alat bukti informasi elektronik. Meskipun telah dijelaskan sebelumnya bahwa dalam pembuktian pidana tidak mengenal hierarki alat bukti atau pembuktian bebas. Hakim memiliki hak untuk menilai alat bukti yang dihadirkan dalam persidangan. Hakim terikat dengan minimum pembuktian yaitu dalam menjatuhkan putusan hakim harus berdasarkan 2 alat bukti yang sah sebagaimana diatur dalam Pasal 183 KUHAP. Dalam Pasal 5 Ayat 3 UU ITE sendiri menyebutkan bahwa keabsahan alat bukti informasi elektronik ini diakui oleh hakim apabila 
menggunakan Sistem Elektronik yang sesuai dengan ketentuan yang diatur dalam Pasal 16 ayat (1) UU ITE, yaitu yang memenuhi persyaratan minimum sebagai berikut:

a. dapat menampilkan kembali Informasi Elektronik dan/atau Dokumen Elektronik secara utuh sesuai dengan masa retensi yang ditetapkan dengan Peraturan Perundang-undangan;

b. dapat melindungi ketersediaan, keutuhan, keotentikan, kerahasiaan, dan keteraksesan Informasi Elektronik dalam Penyelenggaraan Sistem Elektronik tersebut;

c. dapat beroperasi sesuai dengan prosedur atau petunjuk dalam Penyelenggaraan Sistem Elektronik tersebut;

d. dilengkapi dengan prosedur atau petunjuk yang diumumkan dengan bahasa, informasi, atau simbol yang dapat dipahami oleh pihak yang bersangkutan dengan Penyelenggaraan Sistem Elektronik tersebut; dan

e. memiliki mekanisme yang berkelanjutan untuk menjaga kebaruan, kejelasan, dan kebertanggungjawaban prosedur atau petunjuk. ${ }^{10}$

\section{PENUTUP}

\section{KESIMPULAN}

Berdasarkan rumusan masalah dan hasil
tinjauan beserta analisa yang telah dikemukakan maka dapat ditarik kesimpulan yakni:

1. Bahwa alat bukti informasi elektronik baik berupa informasi elektronik maupun dokumen elektronik saat ini merupakan suatu kebutuhan untuk mengungkap tindak pidana yang dipersidangkan di pengadilan, terutama yang sulit pembuktiannya dan atau masih tidak cukup meyakinkan alat bukti sebagaimana diatur dalam KUHAP. KUHAP tidak mencantumkan tentang bukti elektronik namun hakim bisa menggunakan bukti elektronik ini sebagai alat bukti yang menambah alat bukti lain diluar KUHAP. Alat bukti informasi elektronik dalam Pasal 108 huruf (b) Undang-undang Nomor 6 Tahun 2011 serta hasil cetaknya memiliki kedudukan yang sama dengan alat bukti

\footnotetext{
${ }^{10}$ Indonesia, Undang-undang Nomor 11 Tahun 2008 tentang Informasi dan Transaksi Elektronik, Pasal. 16. 116
}

dalam Pasal 184 KUHAP khususnya dalam pemeriksaan tindak pidana Keimigrasian, karena dalam KUHAP tidak mengenal adanya hierarki/tingkatan alat bukti mana yang harus diajukan terlebih dahulu guna mendukung proses pemeriksaan tindak pidana Keimigrasian. Dalam hal ini alat bukti informasi elektronik dalam Pasal 108 huruf (b) memiliki kedudukan cukup penting di samping alat bukti lainnya karena dapat membantu meyakinkan hakim dalam memutuskan suatu perkara di samping alat bukti yang terdapat dalam Pasal 184 KUHAP.

2. Kekuatan pembuktian alat bukti informasi elektronik sebagai alat bukti di pengadilan nampaknya masih dipertanyakan validitasnya karena sangat rentan dimanipulasi. Dalam praktek pengadilan di Indonesia, penggunaan alat bukti informasi elektronik sebagai alat bukti yang sah memang belum biasa digunakan, seperti halnya dalam pembuktian tindak pidana Keimigrasian. Kebutuhan alat bukti informasi elektronik dalam Pasal 108 huruf (b) Undang-undang Nomor 6 Tahun 2011 tentang Keimigrasian dalam prakteknya didukung oleh Undangundang Nomor 11 Tahun 2008 tentang Informasi dan Transaksi Elektronik sudah secara tegas memberikan dasar hukum mengenai kekuatan hukum alat bukti informasi elektronik dan syarat formil dan materil alat bukti informasi elektronik agar dapat diterima di persidangan. Dalam hukum acara pidana tidak megenal adanya hierarki alat bukti. Layaknya kedudukan alat bukti, kekuatan alat bukti informasi elektronik tidak mengenal alat bukti yang lebih tinggi atau yang lebih kuat dalam perkara pidana Keimigrasian.

\section{SARAN}

Saran yang dapat dikemukakan berdasarkan kesimpulan adalah sebagai berikut: 1. Mempergunakan alat bukti informasi elektronik maupun hasil cetaknya dalam pemeriksaan terkait dengan tindak pidana Keimigrasian yang dilakukan oleh Warga Negara Indonesia maupun Warga Negara Asing yang melanggar ketentuan umum Undang-undang Nomor 6 Tahun 2011 tentang Keimigrasian. 
Kekuatan Alat Bukti Informasi..........(Budy)

2. Dengan kemajuan teknologi dan perkembangan teknik informasi yang semakin cepat maka aparat penegak hukum juga harus mengikuti perkembangan jaman dengan segera mengakui bahwa alat bukti informasi elektronik harus diakui dan dapat dijadikan sebagai alat bukti di persidangan mengingat sudah banyak ketentuan perundang-undangan yang telah mengakui alat bukti informasi elektronik maupun hasil cetaknya sebagai alat bukti yang sah dalam pemeriksaan maupun pembuktian tindak pidana.

3. Memberikan pendidikan dan pelatihan digital forensik bagi PPNS Keimigrasian guna menambah bekal pengetahuan mengenai kemampuan ITE dalam memeriksa dan mengolah alat bukti tindak pidana Keimigrasian khususnya alat bukti yang diucapkan, dikirimkan, diterima, atau disimpan secara elektronik atau yang serupa dengan itu dalam kegiatan penyidikan tindak pidana Keimigrasian.

4. Mengoptimalkan laboratorium forensik yang ada di Direktorat Jenderal Imigrasi dengan menambah alat berupa digital forensik serta meningkatkan koordinasi dengan instansi lain seperti Kepolisian dan Kementerian Komunikasi dan Informasi dalam hal digital forensik untuk mendukung pemeriksaan alat bukti informasi elektronik dalam rangka penegakan hukum terhadap tindak pidana Keimigrasian. 


\section{DAFTAR PUSTAKA}

\section{Buku}

Hamzah, Andi. Hukum Acara Pidana Edisi Revisi, cet. 3: Jakarta: Sinar Grafika, 2004.

Harahap, M. Yahya. Pembahasan Permasalahan dan Penerapan KUHAP-Penyidikan dan Penuntutan. Jakarta: Sinar Grafika, 2008. Pembahasan Permasalahan dan Penerapan KUHAP: Pemeriksaan Sidang Pengadilan, Banding, Kasasi, dan Peninjauan Kembali, Edisi Kedua. Jakarta: Sinar Grafika, 2008.

International Organization for Migration. Petunjuk Penanganan Tindak Pidana Penyelundupan Manusia - Pencegatan, Penyidikan, Penuntutan dan Koordinasi di Indonesia. Jakarta: International Organization for Migration, 2012

Prinst, Darwan. Hukum Acara Pidana Dalam Praktik. Jakarta: Djambatan, 1998.

Sasangka, Haridan Lily Rosita. Hukum Pembuktian Dalam Perkara Pidana. Bandung: Mandar Maju, 2003.

Soemitro, Ronny Hanitijo. Metodelogi Penelitian Hukum dan Jurimetri. Jakarta: Ghalia Indonesia, 1988.

Subekti. Hukum Pembuktian. Jakarta: Pradnya Paramita, 2001.

Suryono, Sutarto. Hukum Acara Pidana Jilid II. Semarang: Badan Penerbit Universitas Diponegoro, 2004.

Santoso, M. Imam. Perspektif Imigrasi Dalam Migrasi Manusia. Bandung: Pustaka Reka Cipta. 2012.
W. Gulo. Metodologi Penelitian. Jakarta: PT Grasindo. 2002.

\section{Peraturan Perundang-Undangan}

Indonesia. Undang-Undang Nomor 8 Tahun 1981 tentang Hukum Acara Pidana. . Undang-undang Nomor 11 Tahun 2008 Tentang Informasi dan Transaksi Elektronik. . Undang-undang Nomor 6 Tahun 2011 Tentang Keimigrasian. . Penjelasan atas Undang-Undang Nomor 19 Tahun 2016 tentang Perubahan atas Undang-undang Nomor 11 Tahun 2008 Tentang Informasi dan Transaksi Elektronik. Penjelasan atas Peraturan Pemerintahan Republik Indonesia Nomor 31 Tahun 2013.

\section{Internet}

"Pengkajian: Kekuatan Nilai Pembuktian Terhadap Alat Bukti Elektronik Dalam Penanganan Tindak Pidana", Kejaksaan Republik Indonesia:

https://www.kejaksaan.go.id/unit

Kejaksaan.php?idu=28\&idsu=35\&id=418 20 Agustus 2017 